\title{
Influence of Indigenous Philosophy on the Administrative Culture of Nepal
}

\author{
Dipak Kaphle, Dinesh Panthi ${ }^{2 *}$, Eka Ratna Acharya ${ }^{3}$ \\ ${ }^{1}$ Research Centre, Nepal Sanskrit University, Kathmandu, Nepal \\ ${ }^{2}$ Department of Mathematics, Valmeeki Campus, Nepal Sanskrit University, Kathmandu, Nepal \\ ${ }^{3}$ Central Department of Education, Tribhuvan University, Kirtipur, Nepal \\ Email: dktdip@gmail.com, *panthid06@gmail.com
}

How to cite this paper: Kaphle, D., Panthi, D., \& Acharya, E. R. (2020). Influence of Indigenous Philosophy on the Administrative Culture of Nepal. Advances in Historical Studies, 9, 174-184.

https://doi.org/10.4236/ahs.2020.94015

Received: September 2, 2020

Accepted: November 17, 2020

Published: November 20, 2020

Copyright (c) 2020 by author(s) and Scientific Research Publishing Inc. This work is licensed under the Creative Commons Attribution International License (CC BY 4.0).

http://creativecommons.org/licenses/by/4.0/

\section{(c) (i) Open Access}

\begin{abstract}
Indigenous philosophy is an organized form of human activities for human and humanity that people have been practicing and adapting for a long time as the custom of Nepal and its territory. The present constitution of Nepal has been given importance to the protection of religions and cultures that has been going on since time immemorial. The Vedas is the source of knowledge of human life and the study of Vedas, Manusmriti, Kautilya's economics, Yajnavalakya Smriti, Shukra Policy etc., are in the form of Indigenous philosophy that helped to improve the administrative system of Nepal. In this article, we investigated about the practice and influence of Indigenous Philosophy in administrative culture of Nepal.
\end{abstract}

\section{Keywords}

Indigenous Philosophy, Immemorial, Administration, Memorandum, Security, Justice

\section{Introduction}

Administration is the executive mechanism and working system developed by the state administrators (Epstein and Gang, 2010). Administrative work has been going on in Nepal for a long time. Societal behavior that has been going on from very development of the society is making the administrative system indestructible. Such an act is called indigenes phenomenon, in Nepali vernacular this can be term as Sanatan custom with regarding Nepali culture that relate to immemorial or eternal. Originally, the deities names used in Eastern philosophy such as Shiva, Vishnu, Brahma, Lakshmi, Durga, Saraswati is referred to as indigenous rituals or sanatan (deities for perpetual), meantime the human religion that 
has been going on since time immemorial is also called sanatan along with Hindu religious traditions based on Vedas, Puranas, Tantras, Idolatry. As the Constitution of Nepal mentions the protection of religion and culture from time immemorial or eternal in the explanatory section of secularism, the word sana$\tan$ has constitutional foundation (Constitution of Nepal, 2015). Now, days this word is popularly used as indigenous knowledge which relates very early to recent social human activities in different communities.

The Vedas are at the forefront of such organized collections of ancestral sages who emerged during the development of human civilization and succeeded in spreading oriental civilization to the world (Khanal, 2017a). As a source of knowledge of Eastern civilization and culture, the Vedas are at the forefront of the world's oldest literature (Durant, 2006). In the context of the Vedas, which is a source of knowledge for the conduct of human life and being considered as knowledge, the relationship between indigenous or eternal philosophy such as the Vedas and Manusmriti, Shukraniti, Kautilya's Arthasastra, etc. and these are connected in administrative system of Nepal.

\section{The Vedas}

The Vedas, which emphasize on Jyana (knowledge), Karma (deeds/duties) and Upasana (devotional worship) for the betterment of man, are believed to have been obtained with the development of man. Through Karma (prescribed duties) purity of mind can achieved. Through Upasana that is devotional worship pointed to concentration of mind. And through Jyana, moksha (liberation) is attained. The Vedas, divided into Rig Veda, Yajur Veda, Sama Veda and Atharva Veda, have given direction to the overall administration (Vedas Wikipedia). The position of the general people was high in the Vedic period (Acharya, 2015). In the committees formed then to represent the people, qualified, just, mature, experienced people of governance were selected or elected. The people in the committee worked very seriously and solved all of the problems of the nation. There were no acts against the interest of the people. It was customary to make appropriate decisions by respecting the views of all members. In order to keep the state organized, the committee would have created an environment to work independently. The committees worked with heart, mind and karma dedicated to the nation and the people. The Vedic system of government was based on a system that arose from the people, was approved by the people and was accountable to the people (Gyawali, 2012). Experienced and able people were chosen or selected for decision-making, collective decision was given priority, prior to decision issues were discussed extensively and decisions were taken by consensus as much as possible and if not, decisions should be taken by majority only; such practices portrays the nature and character of the Vedic era regime (Knowledge of Vedas, 2018).

The various Richa (verses or couplets) of Rig Veda mentions defense system, law making, observance of time and rules, crime and its control, observance of 
duty, punishment, fines, family relationship management, social relations management, misconduct, business control, agriculture system, animal husbandry system, state Tax collection, administration of justice, establishment of peace, provision of freedom and provision of human equality. In 108 Suktas (hymns) of Rig Veda it is mentioned that the best means of acquiring knowledge is from education and the best way to acquire knowledge is the study of books. Only those who set goals and strive for them can achieve wealth and success. Land, Saraswati and Vani (the voice) give happiness to human. Work should be done to increase the pride of motherland, native culture and language. Those who do their works with patience find happiness. The one who gives alms to others immediately gets something. Setting a goal and achieving it through karma is puja, a real offering to god. A non-cooperative person can never be a patron. Even if one has to go to war at the time of invasion and calamity, he/she should and inspire heroes for war and awaken the consciousness of knowledge in the people. Through proper nutritional diet and physical exercises, one can obtain physical strength. The goal is achieved when strength is increased through body, mind, and wealth. Man has to cultivate intellect, give wealth and speak the truth. $\mathrm{Hu}$ man life is not possible without air, food and water. The Rig Veda contains ideal knowledge that can be used in regime functionary. It is also a sociological approach to administration, foreign relations and diplomacy.

Emphasizing the importance of self-control and sense of duty, Rig Veda emphasizes on collective life, virtuous life and duty-oriented lifestyle. Vedic practices such as decentralized administration, people's problems solved by the people-as far as possible, decision on the basis of positional hierarchy and complaints lodging at the higher level are equally important in today's administrative system of Nepal. On the other hand, the Yajurveda discusses human health. Causes and treatments of ailments, crime and its control, army system, national defense, forest protection, water and irrigation system, leadership, justice, peace, non-violence, human duty, respect for human rights and individual's dignity, protection from fear, terror, business management, tax management, etc. are discussed. In this Veda, emphasis is laid on good diet, exercise and karma to become a better self physically, mentally, personally and in community. Any action should be done in a simple and proper way. If leaders, administrators and masters become crooked, so will their followers. It harms the society. We have to accept the truth, take sides of it, give up greed, fearlessly walk on the path of progress and preach what we know. These issues mentioned in the Yajurveda are observed as an ideal model of governance in today's Nepal. The issues mentioned in the Yajurveda are relevant in today's administrative culture of Nepal (Shrestha and Rijal, 2016), including the provision of Nepal army for the defense of the country, police for peace and security, courts for administration of justice and provision of health and nutrition for the protection of human life.

Similarly, most of the subjects in the Sama Veda are from the Rig Veda. Mainly covering music Sama Veda also includes topics such as defense, protec- 
tion and observance, crime and crime control, duty, punishment, family relations and law, justice and leadership qualities. Work, anger, greed, lust and ego are the 5 disorders of human beings and they should be destroyed. It is necessary to keep the environment clean, be soft-spoken and gentle, to keep the body, mind and surroundings clean, to win the struggle of life, to save money only for contingency expenses. A person who differs in speech and action can never have peace of mind. The Sama Veda idealizing the concept that the human happiness is in a person who is motivated by knowledge and strives to achieve the goal with good deeds and envisions further a state functionary with an administrative system of suitable and conducive leaders, having the ability to guide with the quality of immediate action and of remarkable pace.

Another form of Veda, Atharvaveda, mainly discusses the method of medical treatment. Including spectrum of issues such as health, medicinal importance, drug production, pharmaceutical trade and other trade, commerce, minerals, crime control, non-violence, peace, education, family management and relations, assembly, members of the constituent assembly, it has also detailed further that human's first happiness is in maintaining healthy body, strengthening unity, work for the betterment of the nation, having sweet disposition, giving importance to relations and life, being away from bad habits like beating, betrayal, violence, sinful deeds, lust, anger, hatred, greed, ego and avoiding of adultery, murder, theft, abortion, drunkenness, misconduct, and lying. The practices of different kinds of person judging his/her traits, if assigned to the responsibility of the position, can achieve success are discussed thoroughly. For example, a person who knows how to use weapons and can lead chivalry to destroy the enemy should be in armed force, pharmacologist to get rid of diseases, intellectually curious with an inquisitive mind person for education, five benefactors termed as Pancha Valadmi for justice. In the course of the policy rules, it has been said that while treating oneself, one should not seek too much in a way that violates the rights of others. Thus, the Atharva Veda has been an important doctrinal basis for equal treatment, exercise of human liberty, just law-making, and protection of the rights of others for Nepal's administration and judiciary.

The Vedas discuss defense, security, protection and law obedience (Rai, 2017). These four things are the basics of administration. The overall function of today's administration of Nepal is to protect the country and the people, to ensure fearless/secure environment to live, to make special arrangements for the backward and those in need of special assistance, and to respect national and international law with dignity. These four issues mentioned in the Vedas, can be understood as the ideals of administration for Nepal.

\section{Manusmriti (Manu Memorandum)}

Manusmriti or Manu memorandum, also an indigenous philosophy, discusses mainly about punishment to control abuses and carried to right track to the society. Manusmriti discusses the origin, importance, nature and form of punish- 
ment, the purpose and quantity of punishment in relation with state execution, judicial and administrative system. In addition, it is also mentioned on how a state has to treat foreigners. The issues related to diplomacy such as the qualities and qualifications of an ambassador, subjects under diplomatic administration, the need for ambassadors, their importance, nature of work, efficiency are also mentioned (Acharya, 2018).

Similarly, the administrative leadership to be taken by the head of state by making arrangements related to security and defense administration, tax administration, taxation system and intelligence has been mentioned. There should be one village head and officer in each village, the problems of the village should be sent up only if the village head cannot solve them and the hierarchical positions from bottom to top in order to address such problems are clearly described. The main issue of Nepal's administrative system has been to decentralize the administration and to solve the people's problem at the local level as much as possible.

The Manusmriti, which demands state being in-tolerant to corruption and wrongdoing, also mentions the administration of justice too. Showing the need for the structure of the justice system, the issues and reasons that can lead to disputes in the society are mentioned. The merits and demerits of the judiciary, the provision of witnesses, the false witnesses, the testimony of witnesses, the oath, the penal system, the physical measurement of weight\& quantity, the consumption, the civil and criminal liability, the punishment according to the offense and the amnesty, the compensation, the tax and the corruption are widely discussed. Many of the themes mentioned in the Manusmriti seem to be equally necessary in Nepal's administrative system today. Manusmriti seems to be the ideal philosophy of Nepali administration to make the country's administration people-friendly and create a corruption-free and disciplined administrative system (Acharya, 2002).

\section{Kautilya's Arthasastra-Kautilya's Economics}

Kautilya's Arthasastra or economics is mainly related to the state system. The economics, which deals with a wide range of issues related to administration, includes the conduct of ministers, appointment of ministers for aiding and abetting the government, selection and appointment of spies, security arrangements, dealings with enemy countries, appointment of ambassadors for various functions, detention or incarceration practices' conduct, king or head of state's duties.

Arrangements have been made for the use of land, establishment of districts, work, duties and conduct of those working in different positions and treaties with various neighbors, conflicts, agreements, compensation, and assistance in case of calamity. Issues related to defense administration such as military provision for the defense of the state, establishment of peace and victory over the enemy have been discussed. Kautilya economics, which focuses on diplomacy, finance, defense, land, industry, business, taxes, peace and security, personnel management and the overall issues of the administrative sector, states that ad- 
ministration should be based on a merit system.

The administration should be run on the basis of law and policy, the work should be done by the employees in the post at the same time the work, duties and responsibilities of each office and officer should be clearly defined. The promotion of the officers should be based on the quantity and quality of work. Misuse of state coffers and corruption reports should be taken from spies or intelligence and subsequently penalize the culprits. In Kautilya Arthasastra, including the provision of penalties and rewards, it elaborates further on keeping the accounts of revenue and expenditure in order, checking and inspecting the work and work quality, and strengthening, efficient and effective administration of defense, security, economy and diplomacy.

From time immemorial, human beings have been formulating national policies in economic, social, political, cultural and other fields according to the situation of the country and time. Kautilya, known as the teacher of religion, politics and diplomacy, contributes to the regulation of human behavior by bringing forward the most important concept of moral development of the human race. According to his theory, no creature should oppress anyone. If there is a characterless king, neutral people, skeptical decision and fearless criminal in any state, such states fall under the spell of their neighbors (Khanal, 2017b). Before negotiating with anyone, one should know his nature. With this comprehensiveness of Kautilya's economics on state handling, it will certainly is directive philosophy for Nepal's administration, foreign relations management, economic activities, peace and security, etc.

\section{Yajnavalakya Smriti or Yajnavalakya Memorandum}

Maharishi Vaishampayan's disciple Yajnavalkya is also associated with the Yajurveda. The time immemorial things he reminded are just as important in today's administrative system. He has mentioned about the issue of monarchy in running the state. The Yajnavalkya smriti or memorandum discusses the king, ministers and other officials of the state administration. It has been mentioned that the money brought by the person appointed to collect revenue in the state should be deposited in the state treasury, after the completion of the work, the king should discuss with his intelligence, envoys and ministers, and meet and discuss with the minister and army chief in the afternoon. Since the main mantra of the state is diplomatic relations, some issues of relations with other states should be kept secret. Considering the dialogues as the main stepping stone of foreign administration, it is the duty of the country to be well-informed of the activities of such states on a daily basis. Since with bordering countries is relations are often hostile, with countries next to neighbors are amicable and with countries at distant always be neutral, states should pay attention to the nature and tendency of other countries in conducting diplomacy.

Appropriate policy should be followed among the patience/prudence, cost, penalties and distinctions or discrimination as per the requirements. In the process of Nepal's unification, Prithvi Narayan Shah's strategy of prudence 
(discussion, negotiation), cost (giving something), discrimination (opening the other side's weakness and secrecy), punishment (controlling by giving appropriate punishment) had lost great importance. Strategies such as making treaties with foreigners who are hostile to their state, waging war, respecting them, ignoring them, taking the side of another powerful state, double standards, and dividing the army may also be necessary at the same time in running a state. The king, the ministers, the people, the border guards, the money managers, the army and the friends are considered the seven arms (saptaangs) of the state (Knowledge of Vedas, 2018). These saptaangs should punish the miscreants of the state. Decision makers should not give absolution to their relatives if they are misbehaving, the law should be used equally, punishment is not only a judicial but also an administrative matter, and so the decision-making authority should cultivate judicial and administrative recognition.

Nepal's justice and administrative system, the rule of law, the decision of the quasi-judicial officer to decide the punishment, the conduct of foreign policy and other issues of running the state seem to be guided by the Yajnavalkya Smri$t i$, which is the eternal philosophy of Indian sub-continent.

\section{Narada Smriti or Narada Memorandum}

Narada smriti or Narada memorandum is mainly related to administration and execution of judicial system. The main areas of contention in the judiciary and the judicial process are the causes, branches of law, logic, discretion, tradition, right to hear, fair justice, evaluation of the duties and rights and obligations of the judge, qualification of a judge, evaluation of evidence, false banknotes, claim fund, weight of evidence, decision, prompt justice etc. have been widely discussed in the memorandum. Criminal issues such as crime, humiliation, assault and gambling have been discussed and mentioned the legal provisions of civil and criminal nature (Narada Bhakti Sutra, 2018).

Within the administrative system of Nepal, this sanatan or time immemorial philosophy of administration of justice has direct relationship and is seen as the main guiding principle of justice management. Narada smriti influence over Nepal's civil and criminal legal system and administration of justice justifies the influence of this indigenous philosophy (Narada Bhakti Sutra, 2018).

\section{Shukra-Niti (Shukra Policy)}

The Shukra policy articulates well mainly on the issues related to the running of the state, mentions the functions of the state, the qualifications and duties of the various officials of the state, the policies related to the interests of the king and the people, and other relative policies (Pranav Kumar, 2018). The management of the state treasury, education, arts, monarchy, army system and other issues are also directly related to the administration system. Punishing those who do wrong is to make them inclined towards duty and justice, the security of the government workplace should be provided by the police and the security per- 
sonnel should be a group that knows the policy of treating them with love, humble, skilled in wielding weapons. There should be an arrangement in the administration to take information from the police and listen to it. Strangers should be allowed in only after their identifications registered.

Similarly, a state-appointed spy should be punished for giving false information. Information of important persons of the state should be obtained secretly, security arrangements should be made for the people and state operational officers, employees who cause grief to the people should be removed, first time wrongdoers should be reminded in private, deliberate wrongdoers should be removed, direct monitoring of administrative activities should be facilitated by benefits of doubt by the people not by the officials.

An advisor without lust, anger, greed, should be appointed so as to give advice and rectify when the king is on a bad path and can guide him to the right path with wisdom. Mentioning long list of virtues for public servant to have, it stated to work whole-heartedly, be satisfied with whatever salary received, be soft-spoken, do good to others, give good opinion, be able to administer justice, behave appropriately, be contented, proud but not slanderous, and be prudent. Describing the terms for disqualification of civil personnel it further elaborates on the job description of every official position. Details of the work of the chief who considers or calibrates the work of the king, the secretary who decides the hierarchical positions within army, the minister working on the policies and other positions of the state are also presented. The person should be given as many rights as he/she deserves. Those who can do more work should be appointed to higher posts. There is no unqualified person in the world and thus be given the job he/she is capable of. The new tax and fee should not cause grief to the people. The conduct of the employees clearly states what should be done and what should not be.

The work should not be done without a written order and the employer should give a written order. Subsequently, such written orders should be kept as records for future reference. The revenue, finance's accounting, income and expenditure accounts should be correct, and recorded. The method of preparing the accounts and official write off, method of signing according to rank, final administrative decision approved by more than three officers, and the consent of the concerned officials are mentioned as general administrative practices. Issues like measurement, weight, time, leave, honorary degree/recognition have also been raised in the policy. Those who are involved in running the state should be paid on the basis of work itself or work hours, should not be paid enough to feed their families, should be paid according to merit. If paid less they opt to corrupt the system and take bribes. There are generally three types of employees: slow-paced, moderate-pace and fast one. The stipend and remuneration of these three should be determined accordingly, the employee should be given leave to do housework, leave should be given on holidays, and paid leave should be given to the sick. Frequent or chronic patients should be replaced or if that employee is of high morale and contributed very well in past should be given half salary. 
Long service personnel should be given half salary until he is alive, give scholarship to his family. High official should advice to the sub ordinates from time to time and if only opt for insults or workplace harassments, they will turn into enemy. Man should not be discriminated only by birth, he is judged on the basis of his merits and deeds. In Shukra niti, many issues of state administration have been presented. In Nepal, there various service groups have been provisioned to run the administration. There are many other insights in the form of indigenous that is sanatan philosophy in Shukra niti. It mentions the structure and management of the court, border disputes, attacks, robberies, violence, duties of husband and wife, patriarchal properties and beneficiaries. Thus, Shukraniti is still relevant to Nepal's administration and administration of justice.

\section{Other Smriti (Memorandum)}

There are many memories as indigenous philosophy in our societies that structure and management of the court, border dispute, robbery, and violence, duties of husband and wife, share, childlessness have been mentioned in Jupiter smriti. Inspired by ethical and thought oriented sentiments. Similarly, the Buddhist philosophy seeks to guide human conduct and behavior to the path of right saying that there is sorrow in the world, there is a cause of sorrow, and there are ways to remove sorrow. Jupiter's memorandum and the spirit of Buddhist philosophy are very important in the modern administrative system in our societies.

\section{Influence of Indigenous Philosophy in Various Fields}

The beliefs of various indigenous philosophies presented above have mentioned the basis of human behavior and governance as the code of conduct. Indigenous philosophy seems to have an impact in the following areas for achieving human prosperity through appropriate administrative, economic, social, political and cultural practices of indigenous knowledge. So, sanatan and indigenous knowledge are used as the synonyms to each other that represent the social rituals. So, the indigenous philosophy influences the various fields like administration, justice, daily rituals and our knowledge in educational systems.

\subsection{Administrative Field}

Indigenous practices that have been going on since time immemorial, modifying over time but never perishing, have been on integral part of human life. Administration is the administrative arrangement made by the government for the safety and welfare of the people living in their country. The main area of administration is planning, organizing, directing and controlling. Indigenous philosophy has an impact place in modern administration to strengthen inter-governmental relations through administrative means, to provide services through necessary organizational structure, to full fill basic human needs, to maintain good governance in working practices, to work in public interest by formulating public policy and to assimilate social change. 


\subsection{Economic Field}

Financial management is an important area of administrative work. Indigenous philosophy has given special importance to human welfare, judicial distribution, use of alternative means, reduction of deficit, increase in profit, and balance between supply and demand. Indigenous philosophy which is directly related to the main areas of economics such as consumption, production, exchange, distribution, etc., has motivated those involved in financial management to work in good spirits. The traditional view that if the available resources are not distributed or used, it is somehow destroyed is equally important in modern times. The Sanatan philosophy which is somehow Connected with all field of micro and macroeconomics, is equally important in modern economic thought that man lives by material means rather than ideals.

\subsection{Political Field}

Politics is the social process development for the protection of human livelihood, maintaining peace and order in the society, respecting the fundamental rights of the people, developing the system to govern the state, maintaining proper balance in the formulation and implementation of national and international policy, indigenous philosophy has motivated the leaders to maintain integrity and discipline in politics. The idea of impartiality and neutrality in the pursuit of human happiness by those chosen by human beings for the good of mankind is still as important in the modern world political environment as is guided by Sanatan or by the indigenous philosophy.

\subsection{Culture Field}

Since Philosophy is the way of looking at life and the universe, it reflects and analyzes spirituality and material things. Culture is the collective form of values, beliefs, thoughts, reflections, emotions, etc., that have been practiced and followed from tradition, In this context, the search for reality in the physical and spiritual realm of the world has been going on continuously in conjunction with the true knowledge envisioned by Sanatan philosophy. According to the essence of the Sanatan philosophy that all human being are children of good, the practice of treating all the world. Since creation is based on equal participation and coexistence of men and women, they should be given equal dignity. A good man is full of knowledge, always content, able to control his heart, truthful, generous, kind and humble. These human qualities required by all human beings are described in Sanatan philosophy. Since Sanatan philosophy has directed us to work with good intentions to make people happy and prosperous for the benefit of all people, it has great significance in the development of culture.

\section{Conclusion}

The scripture related to indigenous philosophy is not a matter of supporting or belittling anyone, sect or religion, but a matter of the need to run the state, the 
method of managing the system and the principles for managing the state. Many system such as external security, war, peace, human rights, diplomacy, good governance, kings, ministers, office bearers, and duties, qualifications of office bearers, work, and remuneration are found in indigenous or sanatan philosophy. Since sanatan philosophy or Darshan is not a law itself, it is only a matter of scripture. So, it is up to the government to make legal and policy arrangements for appropriate issues-learning from our legacy documents. The subjects raised in the scriptures are not even orders or axiom, they are ideas and alternatives so they can be used in time. In sum, while studying the sanatan Darshan presented by various scholars after translating the scriptures in Sanskrit language to various languages, the above-mentioned subjects related to state administration seem to be equally important and relevant in today's administration, administration of justice, diplomacy politics, cultural development and financial management regarding to indigenous philosophy.

\section{Conflicts of Interest}

The authors declare no conflicts of interest regarding the publication of this paper.

\section{References}

Acharya, D. (2018). Manusmriti. Delhi: Kaharr Apps studio, India.

Acharya, E. R. (2015). Mathematics Hundred Years Before and Now. History Research, 3, 41-47. https://doi.org/10.11648/j.history.20150303.11

Acharya, M. (2002). Nepal Culture Shift Reinventing Culture in the Himalayan Kingdom. Delhi: Nice Printing Press.

Constitution of Nepal (2015). Government of Nepal.

Durant, W. (2006). The Story of Philosophy. New York: Avenne of the Americas.

Epstein, G., \& Gang, I. (2010). Migration and Culture. Germany: Discussion Paper No. 5123. https://doi.org/10.1108/S1574-8715(2010)8

Gyawali, S. (2012). Eastern Civilization. Delhi: Oriental Publication.

Khanal, A. (2017a). Impact of Western Culture in Nepal. Kathmandu: Lecture Note.

Khanal, R. (2017b). A Study of Kautilya's Taxation Policy and Its Relevance in Nepal Tax Administration. Kathmandu: Research Centre of Nepal Sanskrit University.

Knowledge of Vedas (2018). Knowledge of Vedas App. Delhi: Kaharr Apps Studio, India. Narada Bhakti Sutra (2018). Vani Dev House. Delhi: Apps Studio.

Pranav Kumar (2018). Vani Dev Home. Delhi: Apps Studio.

Rai, B. (2017). Eastern Philosophy. Kathmandu: Nepal Academic Research Center.

Shrestha, C. B., \& Rijal, S. P. (2016). Nepal Cultural Geography. Kathmandu: Pragati Printers. 